

RESEARCH ARTICLE

\title{
CULTIVATION OF WILD PLEUROTUS SPECIES ON AGRICULTURAL SUBSTRATES AND EVALUATION OF THEIR NUTRITIONAL PROPERTIES.
}

\author{
Anjana Sharma ${ }^{1}$, Neetika Thakur ${ }^{1}$, Savita Jandaik ${ }^{3}$ and Rajender Singh ${ }^{4}$. \\ 1. Shoolini university of biotechnology and Management sciences(Himachal Pradesh). \\ 2. Department of Plant Pathology, Dr.YSParmar University of Horticulture and Forestry, Nauni Solan(Himachal \\ Pradesh). \\ 3. ICAR -Indian Agricultural Research Institue (RS)Katrain, Kulley valley (Himachal Pradesh) 175129.
}

\section{Manuscript Info}

Manuscript History

Received: 20 October 2018

Final Accepted: 22 November 2018

Published: December 2018

Key words:-

Pleurotus species, Agro- waste, Oyster Mushroom, Nutrition

\begin{abstract}
Three wild isolates of Pleurotus were collected from different parts of north western Himalayas. Based on the morphological and cultural traits isolates were identified as i.e P.djamore,P.ostreatus and Pleurotus florida. These three species were cultivated on different locally available substrates in Himachal Pradesh. Different substrates used were paddy straw, wheat straw, soybean straw and maize stalks .All the species of Pleurotus performed well on Paddy straw and soybean straw.. Highest protein content $(2.50 \mathrm{mg} / \mathrm{g})$ was found in P. ostreatus on soybean straw followed by Pleurotus florida $(2.32 \mathrm{mg} / \mathrm{g})$ on same substrate.
\end{abstract}

Copy Right, IJAR, 2017,. All rights reserved.

\section{Introduction:-}

Wild edible mushroom have been integrated part of the diet, especially among rural, urban dwellers and tribal people. Some of the common edible mushrooms, which are predominantly consumed in India are Pleurotus sajorcaju, P. florida, P. platypus, P. djamor, Volvariella volvacea and Calocybe indica (Pan et al., 2008; Ramkumar et al., 2010). Pleurotus species is known as oyster mushrooms, which are widely spread saprophytic macrofungi and distributed throughout the temperate and tropical forests of the world (Gunde Cimerman 1999). Oyster mushroom is consumed all over the world due to its taste, flavor, high nutritional value and some medicinal properties. Many species of this genus are rich in proteins with essential amino acids, polysaccharides, essential amino acids, dietary fibers, important minerals and some vitamin (Sharma and Jandaik,2017). Cultivation of oyster mushroom has recently increased tremendously throughout the world because of their abilities to grow at a wide range of agrobased residues. These white-rot fungi are useful decomposers of various agricultural wastes .Pleurotus spp. are the most talented group among the cultivated mushrooms, which have ability to degrade many lignocellulosic substrates and are capable to colonize successfully on these substrates (Patrabansh and Madan, 1997). Agriculture residues are the major source of lignocellulosic materials, which is best substrate for solid state fermentation of edible fungi. Pleurotus spcies has very high saprophytic colonizing ability and can degrade wheat straw efficiently Zadrazil (1980). Growing oyster mushrooms convert a high percentage of the lignocellulosic materials to fruiting bodies. Therefore, cultivation of Pleurotus species on various agricultural residues offers high value products with nutritional and medicinal properties. Also, mushroom production gives additional or alternative income to farmers looking for a value-added product and a way to supplement farm income while making use of byproducts or coproducts from other crops.

Corresponding Author:-Anjana Sharma.

Address:-Shoolini university of biotechnology and Management sciences(Himachal Pradesh). 


\section{Materials And Methods:- \\ Collection:-}

All the species were collected from the different localities of North West Himalayas

\section{Isolation and maintenance of pure culture:-}

Pure culture of collected wild species was raised from the pileus portion of the mushroom where the lamellae join the stipe. For raising the culture a small piece of mushroom tissue was cut and removed with the help of sterilized scalpel under aseptic conditions and subsequently sterilized by dipping in $0.02 \%$ mercuric chloride solution and inoculated into the pre-prepared sterilized MEA slants. The inoculated MEA slants were stoppered with the cotton plugs and incubated at $28 \pm 2{ }^{\circ} \mathrm{C}$ temperature. The total operation of culturing was done aseptically under laminar flow. After 3-4 days (depending upon species), white mycelium started emerging and spreading on the PDA slants. Purification of the culture for further maintenance and utilization in experiments was done through repeated subculturing. Then the equal bits of the mycelium were put in petriplates and the growth was measured on daily basis in triplicates.

\section{Spawn Preparation:-}

The spawn of selected isolates of Pleurotus was prepared following the standard technique.

\section{Evaluation of substrates for sporophore production:-}

Pleurotus species were grown on different agricultural wastes like paddy straw, wheat straw, soybean straw and maize stalks . These agricultural wastes were chopped, dried and soaked in water for overnight and then drained off the excess water. The moist substrates were steamed under pressure inside the autoclave for 40 minutes at 15 psi. After sterilized substrates were taken out of the autoclave and allowed to cool down at room temperature. Substrates were next day spawned with spawn of different species mentioned above @2.5\% .The filled bags were tied with rubber band and 6-8 small holes $(1 \mathrm{~mm})$ made around the bags. The mushroom bags were kept in a dark room, where temperature ranged between $24-28^{\circ} \mathrm{C}$ and relative humidity $80-85 \%$ for the spawn run. Polythene bags were teared off after completion of spawn run and removed the side without disturbing the beds of mushroom and kept on wooden racks. To provide adequate moisture, daily water was sprayed on mushroom beds. Usually 3-4 days after opening the bags, mushroom primordial began to form. Fruit bodies were harvested in about 3-4 days after maturity. Harvesting was done by grasping the stalk and gently pulling or twisting the mushroom from substrates level.

\section{Observations:-}

were recorded in terms of days to spawn run and first flush, pin head initiation and total yield of fruit bodies .

\section{Nutrtional Studies:-}

Standard biochemical techniques were employed for determining the proximate composition and neutraceutical components of different species of Pleurotus (Fr.) P. Kumn. investigated during the present study.

\section{Estimation of Protein content:-}

Protein estimation was done by the method given by Bradford (1976). Estimation of carbohydrates was carried out by following phenol sulphuric acid method (Dubois et al. 1956; Hedge and Hofreiter 1962).

\section{Results:-}

Three wild isolates of Pleurotus were collected from different regions of North West Himalayas. Collected isolates were identified on the basis of macroscopic and microscopic traits of basidiocarp(Plate 1) and cultural characteristics. Results depicted in table 1 show that Pileus colour of isolate P1 was pink. The surface of pileus was smooth and wavy, stipe length was 1.0-1.5 cm. Spore print was white with spore size of 6.5-9.5 X 3.0- 4.5 $\mu \mathrm{m}$. The isolate was identified as Pleurotus djamore. Isolates P2 was creamish white in colour surface of pileus was smooth

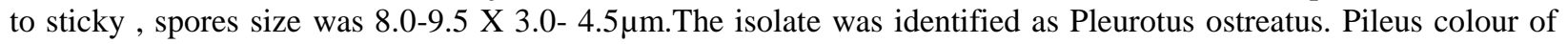
isolate P3 was creamish white, surface of pileus was smooth ,thick and wavy margins with stipe length of 0.5$1.0 \mathrm{~cm}$. Spore print was of white colour . Spore size was 10.3-12.7 x 5.5-7.8 $\mu \mathrm{m}$. Based on macroscopic and microscopic traits the isolates were identified as P sajorcaju. Similarly, many mushrooms were successfully identified based on their morphological and cultural characters by several other workers (Hawksworth , 2004; Fonseca et al., 2008; Gateri,2008). 


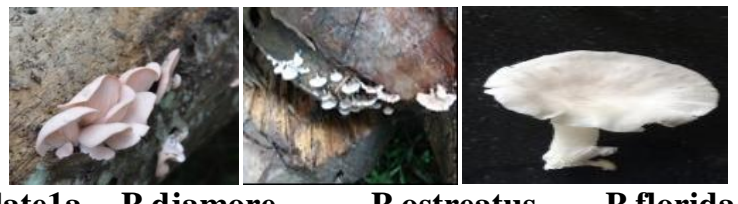

Plate1a. P.djamore P.ostreatus P.florida

Table 1:-Morphological characteristics of the Basidiocarp of different Pleurotus species

\begin{tabular}{|l|l|l|l|l|l|l|l|}
\hline Isolate & $\begin{array}{l}\text { Pileus } \\
\text { colour }\end{array}$ & $\begin{array}{l}\text { Pileus } \\
\text { Surface }\end{array}$ & Margins & $\begin{array}{l}\text { Stipe } \\
\text { length }\end{array}$ & Spore print & Spore size & $\begin{array}{l}\text { Species } \\
\text { Identified }\end{array}$ \\
\hline P1 & Pink & Smooth & Round & $1.0-1.5$ & Creamish & $\begin{array}{l}6.5-9.5 \mathrm{X} \\
3.0-4.5\end{array}$ & P.djamore \\
\hline $\mathbf{P 2}$ & $\begin{array}{l}\text { Cremish } \\
\text { white }\end{array}$ & $\begin{array}{l}\text { Smooth } \\
\text { /sticky }\end{array}$ & curved & $0.5-1.0$ & White & $\begin{array}{l}8.0-9.5 \mathrm{X} \\
3.0-4.5\end{array}$ & P.ostreatus \\
\hline $\mathbf{P 3}$ & $\begin{array}{l}\text { Creamish } \\
\text { white }\end{array}$ & $\begin{array}{l}\text { Smooth, } \\
\text { thick }\end{array}$ & wavy & $0.5-1.5$ & White & $\begin{array}{l}10.3-12.7 \times \\
5.5-7.8\end{array}$ & P.florida \\
\hline
\end{tabular}

The results depicted in table 2 reveals that maximum yield was obtained on paddy straw (standard substrate) followed by soybean straw irrespective of the species. Among different species it was found that P. ostreatus resulted in maximum yield $(840 \mathrm{~g} / \mathrm{kg})$ followed by P. florida $(828.80 \mathrm{~g} / \mathrm{kg})$.All the three species resulted in minimum yield on maize stalks. Pleurotus species are known to grow relatively well on cellulosic /carbohydrate materials as reported by other researchers Zadrazil (1978) and Krishnamoorthy (1981).

Table 2:-Comparative evaluation of different substrates on yield of different Pleurotus species

\begin{tabular}{|c|c|c|c|c|}
\hline $\begin{array}{l}\text { Pleurotus } \\
\text { species }\end{array}$ & Substrates & $\begin{array}{l}\text { Mushroom gro } \\
\text { Spawn } \\
\text { run period } \\
\text { g/kg }\end{array}$ & lays aft & \\
\hline \multirow{4}{*}{ P.djamore } & PS & 15.00 & 19.00 & 798.00 \\
\hline & SS & 17.66 & 23.00 & 771.20 \\
\hline & MS & 19.00 & 21.00 & 463.86 \\
\hline & WS & 21.00 & 22.00 & 547.86 \\
\hline \multirow{4}{*}{ P.ostreatus } & PS & 15.33 & 19.00 & 840.00 \\
\hline & SS & 20.00 & 23.00 & 749.16 \\
\hline & MS & 20.66 & 25.00 & 415.83 \\
\hline & WS & 20.33 & 24.00 & 525.83 \\
\hline \multirow{4}{*}{ P.florida } & PS & 16.00 & 20.00 & 828.80 \\
\hline & SS & 21.33 & 22.00 & 802.00 \\
\hline & MS & 18.66 & 25.00 & 453.60 \\
\hline & WS & 20.66 & 24.00 & 518.00 \\
\hline C.D.(1\%) & & 2.36 & 2.68 & 47.9 \\
\hline
\end{tabular}

Paddy straw =PS, Soybean Straw =SS, Maize stalks= MS, Wheat straw=WS

Table 3:-Estimation of Proteins and Carbohydrates content of three Pleurotus species on different substrates

\begin{tabular}{|l|c|c|c|c|c|c|}
\hline Substrates & \multicolumn{2}{|c|}{ Pleurotus djamore } & \multicolumn{2}{c|}{ Pleurotus ostreatus } & \multicolumn{2}{c|}{ Pleurotus florida } \\
\hline & $\begin{array}{c}\text { Total } \\
\text { Protein } \\
(\mathbf{m g} / \mathbf{g})\end{array}$ & $\begin{array}{c}\text { Total } \\
\text { Carbohydrate } \\
(\mathbf{m g} / \mathbf{g})\end{array}$ & $\begin{array}{c}\text { Total } \\
\text { Protein } \\
(\mathbf{m g} / \mathbf{g})\end{array}$ & $\begin{array}{c}\text { Total } \\
\text { Carbohydrate } \\
(\mathbf{m g} / \mathbf{g})\end{array}$ & $\begin{array}{c}\text { Total } \\
\text { Protein } \\
(\mathbf{m g} / \mathbf{g})\end{array}$ & $\begin{array}{c}\text { Total Carbohydrate } \\
(\mathbf{m g} / \mathbf{g})\end{array}$ \\
\hline PS & 2.00 & 3.81 & 1.95 & 2.91 & 2.45 & 2.95 \\
\hline SS & 2.10 & 2.74 & 2.32 & 2.09 & 2.50 & 2.82 \\
\hline MS & 1.84 & 3.07 & 1.94 & 3.51 & 1.94 & 3.11 \\
\hline
\end{tabular}




\begin{tabular}{|l|l|l|l|l|l|l|}
\hline WS & 2.09 & 3.15 & 2.15 & 3.60 & 2.10 & 3.83 \\
\hline CD & 0.64 & 0.18 & 0.26 & 0.13 & 0.72 & 0.12 \\
\hline
\end{tabular}

Paddy straw $=$ PS, Soybean Straw $=$ SS, Maize stalks $=$ MS, Wheat straw $=$ WS

Relatively higher amount of the protein content $(2.50 \mathrm{mg} / \mathrm{g}$ and $2.32 \mathrm{mg} / \mathrm{gm})$ was recorded in Pleurotus ostreatus and Pleurotus florida respectively grown on soybean straw. The lowest protein content $(1.84 \mathrm{mg} / \mathrm{g})$ was recorded in P.djamore grown on maize stalks. Pleurotus florida showed highest carbohydrate content $(3.83 \mathrm{mg} / \mathrm{g})$ content on wheat straw. Total carbohydrate content ranged from $2.09 \mathrm{mg} / \mathrm{g}$ to $3.83 \mathrm{mg} / \mathrm{g}$ in all the Pleurotus species on different substrates. The digestibility of edible mushroom Pleurotus species proteins is as same as that of plants (90\%) and comparable with meat (99\%) (Wani et al., 2010 ). However, the average of protein content of Pleurotus is most common between 20 and 25\% (Patil et al., 2010). Syed et al., (2009) cultivated P florida on different agro-wastes and reported that soybean straw showed significantly highest yield with maximum crude protein of $23.50 \%$ on dry weight basis.

Naraian and Dixit reported maximum Protein and Carbohydrate content in P. sajor-caju and P. florida grown on wheat straw.

\section{Conclusions:-}

The result of present studies revealed that Pleurotus species can be used for agricultural waste management food supplements to serve as cheap source of protein to solve protein deficiency in poor people. The study also revealed that morphological characteristics and nutritional composition of mushroom depend on the substrate used for cultivation.

\section{References:-}

1. Bradford, MM. (1976) :A Rapid and sensitive method for the quantification of Microgram quantities of the protein utilizing the principle of protein dye binding, Analytical Biochemistry., 72: 248-258.

2. Dubois, M., Gilles, KA., Hamilton, JK., Rebers, PA. and Smith F. (1956):Colorimetric method for determination of sugars. Analytical Chemistry., 28: 350-356

3. Fonseca, GG., Gandra, EA., Sclowitz, LF., Correa, APA., Costa, JAJ. and Levy JA. (2008):Oyster mushrooms species differentiation through molecular markers RAPD. International Journal of Plant Breeding and Genetics. , 2: 13-18.

4. Gateri, M.W. (2008): Cultivation and commercialization of edible mushrooms in Kenya. A review of the prospects and challenges for small- holder production. Acta Horticulture. , 806: 473-480.

5. Gunde-Cimerman N. (1999): Medicinal Values of the Genus Pleurotus. International Journal of Medicinal Mushrooms. ,1: 69-80.

6. Hawksworth, DL. (2004): Fungal diversity and its implications for genetic resource collections. Studies in Mycology., 50: 918 .

7. Hedge, JE. And Hofreiter, BT.(1962) In: Whistler RL, Be Miller JN (eds) Methods in Carbohydrate Chemistry Vol. 17. Academic Press, New York, USA, pp. 1962; 420.

Innov. Rom. Food Bio-technol., 7: 66-76

8. Krishnamoorthy, KV. (1981): Microbial and chemical studies on the cultivation of Pleurotus sajor-caju (Fr) singer (Oyster mushroom)e, M.Sc. Thesis submitted to Department of Agricultural Microbiology, University of Agricultural Sciences, Bangalore.

9. Kurt, S. and Buyukalaca, S. (2010):Yield Performances changes in enzyme activities of Pleurotus spp. (P. ostreatus and P. sajor-caju) cultivated on different agricultural wastes. Biores. Technol., 101:3164-3169

10. Mitra, P., Khatua, S. and Acharya K. (2013): Free radical scavenging and NOS activation properties of water soluble crude polysaccharide from Pleurotus ostreatus. Asian J Pharm Clin Res., 6(3):67-70.

11. Pan, Y., Wang, K., Huang, S., Wang, H., Mu, X., He, C., Ji, X., Zhang, J. and Huang, F . (2008): Antioxidant activity of microwave-assisted extract of longan (Dimocarpus longan Lour.) peel. Food Chemistry. , 106: 12641270.

12. Patil, AS., Ahmed, SA., Telang, SM. And Baig MMV.(2010): The nutritional value of Pleurotus ostreatus (Jacq: Fr) Kumm. cultivated on diffrent lignocellulosic agrowastes. Innovation Romanian Food Biotechnol ., 7: 66-76.

13. Patrabansh, S. and Madan, M.(1997):Studies on cultivation, biological efficiency and chemical analysis of Pleurotus sajor-caju (Fr.) Singer on different bio-wastes. Acta Biotechnol., 17(2):107-122. 
14. Ramkumar, L., Ramanathan, T., Thirunavukkarasu, P. and Arivusevam, N. (2010): Antioxidant and radical scavenging activity of nine edible mushrooms extract. International Journal of Pharmacology., 6(6): 950-953

15. Sharma, A. and Jandaik S. ( 2017):Oyster Mushroom: Answer to Human Ailments. Asian J Pharm Clin Res., 10( 4): 24-27

16. Syed, A A., Kadam, JA., Mane VP., Patil, SS. and Baig, MMV.( 2009): Biological efficiency and nutritional contents of Pleurotus florida (Mont.) Singer cultivated on different agro-wastes . Nature and Science. , 7(1): ISSN 1545-0740

17. Wani, BA., Bodha, RH. and Wani, AH. (2010):Nutritional and medicinal importance of mushrooms. J Med Plants Res., 4(24): 2598-604

18. Zadrazil, F. (1980): Influence of ammonia nitrate and organic supplements on the yield of Pleurotus sajor-caju (Fr) Singer. Eur. J. Appl. Microbiol. Biotechnol., 9:31-35.

19. Zenebe ,G., Weldesemaya, G., Getachew, B. and Solomon Z. (2016) : Growth and yield performance of Pleurotus ostreatus (Jacq. Fr.) Kumm (oyster mushroom) on different substrates. AMB Express., $6: 87$. 